\title{
Anaerococcus rubiinfantis sp. nov., isolated from the gut microbiota of a Senegalese infant with severe acute malnutrition
}

\author{
Maryam Tidjani Alou ${ }^{a}$, Saber Khelaifia ${ }^{a}$, Caroline Michelle ${ }^{a}$, Claudia Andrieu ${ }^{a}$, \\ Nicholas Armstrong a, Fadi Bittar ${ }^{\mathrm{a}}$, Cheikh Sokhna ${ }^{\mathrm{b}}$, Aldiouma Diallo ${ }^{\mathrm{b}}$, \\ Pierre-Edouard Fournier ${ }^{\mathrm{a}}$, Didier Raoult ${ }^{\mathrm{a}, \mathrm{b}, \mathrm{c}}$, Matthieu Million ${ }^{\mathrm{a}, *}$

\begin{abstract}
a Unité de Recherche sur les Maladies Infectieuses et Tropicales Emergentes IRD 198, CNRS 7278, Aix-Marseille Université, Marseille, France b Unité de Recherche sur les Maladies Infectieuses et Tropicales Emergentes IRD 198, CNRS 7278, Campus Commun UCAD-IRD of Hann, Dakar, Senegal

c Special Infectious Agents Unit, King Fahd Medical Research Center, King Abdulaziz University, Jeddah, Saudi Arabia
\end{abstract}

\begin{abstract}
Anaerococcus rubiinfantis sp. nov. strain $\mathrm{mt}^{1} 6^{\mathrm{T}}$ is a new species within the genus Anaerococcus, which was isolated by the culturomics approach from the gut microbiota of an infant suffering from kwashiorkor. A phenotypic, biochemical and proteomic description of this strain is hereby presented alongside a complete annotation of its genome. This strictly anaerobic species forms Gram-positive non-sporeforming cocci. The major fatty acid was hexadecanoic acid. The phylogenetic analysis of strain $\mathrm{mt} 16^{\mathrm{T}}$ showed a 97.9\% similarity level with Anaerococcus vaginalis, the closest validly published species. Its genome is $1,929,161$ bp long with $29.5 \% \mathrm{G}+\mathrm{C}$ content and contains 1808 protein-coding genes and 56 RNA genes, among which are six rRNA genes. Genomic analysis identified $41 / 1864$ coding genes as ORFans (2.2\%) and at least 620/1808 (34.9\%) orthologous proteins which are not shared with the closest phylogenetic species. We believe that the extension of the human anaerobic gut compendium by culturomics is one of the first steps that will improve the understanding of the links between the microbiome and health or disease.
\end{abstract}

\section{Introduction}

Severe acute malnutrition, as the leading cause of child mortality, is a major public health issue [1]. Recently, several studies have highlighted a dysbiosis of the gut microbiota of children affected with severe acute malnutrition [2,3]. In order to characterize the gut microbiota of severely undernourished children, we

Abbreviations: AGIOS, average of genomic identity of orthologous gene sequences; bp, base pairs; COG, Clusters of Orthologous Groups; CSUR, Collection de souches de l'Unité des Rickettsies; dDDH: digital, DNA-DNA hybridization; DSM, Deutsche Sammlung von Mikroorganismen; EI, electron impact; FAME, fatty acid methyl ester; FTP, file transfer protocol; GC/MS, gaz chromatography/mass spectrometry; INSDC, International Nucleotide Sequence Database Collaboration; kb, kilobases; MALDI-TOF MS, matrix-assisted laser-desorption/ionization time-offlight mass spectrometry; MIC, minimal inhibitory concentration; MS, mass spectrometry; NRPS, non-ribosomal peptide synthase; ORF, open reading frame; PKS polyketide synthase; TE buffer, tris-EDTA buffer; SDS, sodium dodecyl sulfate; URMITE, Unité de Recherche sur les Maladies Infectieuses et Tropicales Emergentes.

* Corresponding author.

E-mail address: matthieumillion@gmail.com (M. Million). used the "culturomics" approach, which consists in the multiplication of culture conditions with a variation of media, temperature, $\mathrm{pH}$ and atmosphere conditions to describe a bacterial ecosystem as exhaustively as possible [4]. A new member of the Anaerococcus genus was thus isolated. This genus was created by Ezaki in 2001 and contains eight validated species, the type species being Anaerococcus prevotii [5]. These Gram-positive, obligate anaerobic, and non-spore forming cocci were mostly isolated from human vaginal discharges and various purulent secretions [6].

The recent breakthrough in molecular techniques has allowed additional data such as the complete description of the genome, to be added to classical bacterial classification, which is based on phenotypic and genotypic characteristics and phylogeny based on the 16s rRNA gene [7-9]. Thanks to the decreasing cost of genome sequencing, a new concept of bacterial description [10], taxonogenomics, was created in our laboratory allying classical bacterial classification features to a proteomic description with the MALDITOF profile [11] and a description of the complete annotated genome of the described species [12].

Here follows the description of a new member of the 
Anaerococcus genus isolated from the fecal sample of a Senegalese girl suffering from severe acute malnutrition (kwashiorkor), strain mt16 ${ }^{\mathrm{T}}$ (=CSUR P2032 = DSM 101186).

\section{Materials and methods}

\subsection{Sample information}

The fecal sample of a 7-month-old severely malnourished girl was collected with the consent of the child's parent. At the time of the collection, no antibiotic was administered to the patient and the sample was frozen at $-80{ }^{\circ} \mathrm{C}$ upon reception at the hospital La Timone in Marseille, France. Approval for this study was given by the Institut Fédératif de Recherche 48 (Faculty of Medicine, Marseille, France) under agreement number 09-022. The collected sample was cultivated using the eighteen conditions of standardized culturomics, as described previously [13].

\subsection{Growth conditions}

The ideal growth environment of strain $\mathrm{mt} 16^{\mathrm{T}}$ was determined by testing different temperatures $\left(25,28,37,45\right.$ and $\left.56{ }^{\circ} \mathrm{C}\right)$ under aerobic, anaerobic and microaerophilic growth. Aerobic growth was tested with or without $5 \% \mathrm{CO}_{2}$. Anaerobic and microaerophilic atmospheres were created using respectively GENbag Anaer and GENbag microair systems (BioMerieux, Marcy l'Etoile, France).

\subsection{Morphologic, biochemical and antibiotic susceptibility tests}

Determination of phenotypic characteristics (oxidase, catalase, gram staining, motility, sporulation) was realized as carried out previously [14]. For electron microscopy with negative staining, a $40 \mu \mathrm{L}$ bacterial suspension drop was deposited on formvar coated grids, and incubated at $37{ }^{\circ} \mathrm{C}$ for $30 \mathrm{~min}$. It was then followed by a $10 \mathrm{~s}$ incubation on ammonium molybdate $1 \%$. The grids were dried on blotting paper and finally observed using a Tecnai G20 transmission electron microscope (FEI Company, Limeil-Brevannes, France).

Biochemical features were described using API 20A, ZYM and $50 \mathrm{CH}$ strips according to the manufacturer's instructions (BioMérieux). Since strain mt16 was isolated in anaerobic condition, the strips were all incubated in anaerobic atmosphere using GENbag Anaer (BioMerieux) for 4, 24 and $48 \mathrm{~h}$ for API ZYM, 20A and 50CH strips respectively. In order to test nitrate reduction, we also used an API 20NE strip in the same conditions as the API 20A strip.

Strain mt16 was grown on 5\% sheep blood enriched Colombia agar (BioMerieux) for the fatty acids analysis which was carried out by GC/MS. For this purpose, two samples were prepared with approximately $15 \mathrm{mg}$ of bacterial biomass each harvested from several culture plates. Cellular fatty acid methyl esters (FAME) were prepared as described by Sasser [15]. Briefly, GC/MS analyses were realized by using a Clarus 500 gas chromatograph equipped with a SQ8S MS detector (Perkin Elmer, Courtaboeuf, France). $2 \mu \mathrm{L}$ of FAME extracts were volatilized at $250^{\circ} \mathrm{C}$ (split $20 \mathrm{~mL} / \mathrm{min}$ ) in a Focus liner with wool and separated on an Elite-5MS column $(30 \mathrm{~m}, 0.25 \mathrm{~mm}$ i.d., $0.25 \mathrm{~mm}$ film thickness) using a linear temperature gradient (70-290 ${ }^{\circ} \mathrm{C}$ at $6{ }^{\circ} \mathrm{C} / \mathrm{min}$ ), allowing the detection of C4 to C24 fatty acid methyl esters. Helium flowing at $1.2 \mathrm{~mL} / \mathrm{min}$ was used as carrier gas. The MS inlet line was set at $250{ }^{\circ} \mathrm{C}$ and EI source at $200{ }^{\circ} \mathrm{C}$. Full scan monitoring was performed from 45 to $500 \mathrm{~m} / \mathrm{z}$. All data were collected and processed using Turbomass 6.1 (Perkin Elmer). FAMEs were identified by a spectral database search using MS Search 2.0 operated with the Standard Reference Database $1 \mathrm{~A}$ (National Institute of Standards and Technology (NIST), Gaithersburg, MD, USA) and the FAMEs mass spectral database (Wiley,
Chichester, UK). Retention time correlations with estimated nonpolar retention indexes from the NIST database were obtained using a 37-component FAME mix (Supelco; Sigma-Aldrich, SaintQuentin Fallavier, France); FAME identifications were confirmed using this index. Our results were compared to that of Anaerococcus strains readily available in our in house collection, CSUR, namely Anaerococcus vaginalis CSUR P727, Anaerococcus senegalensis CSUR P156, Anaerococcus murdochii CSUR P1063, Anaerococcus tetradius CSUR P1064 and Anaerococcus octavius CSUR P179.

Antibiotic susceptibility was determined using the antibiotic gradient strip test method with Etest strips (BioMerieux) thus allowing to obtain the minimal inhibitory concentration (MIC) for each tested antibiotic. Inoculum suspension was prepared with a culture of strain $\mathrm{mt} 16^{\mathrm{T}}$ grown on sheep blood enriched Colombia agar (BioMerieux) suspended in a sterile saline solution $(0.85 \%$ $\mathrm{NaCl}$ ) to obtain a turbidity of $0.5 \mathrm{McFarland}$. The inoculum was then plated with cotton swabs on 5\% horse blood and $\beta$-NAD enriched Mueller Hinton Agar (BioMerieux) as per EUCAST recommendations [16,17]. Etest strips (amoxicillin, amoxicillin/clavulanic acid, clindamycin, imipenem, metronidazole, penicillin G, vancomycin) were deposited. The plates were incubated for $48 \mathrm{~h}$ in an anaerobic atmosphere. Elliptical zones of inhibition are formed around the strip and the intersection with the strip indicated the MIC [17]. Escherichia coli strain DSM 1103 was used as a quality control strain. MICs were interpreted according to the EUCAST recommendations [18].

\subsection{Strain identification by MALDI-TOF MS}

Strain mt16 was identified using MALDI-TOF MS technology $[11,19]$. This proteomic analysis was conducted using a Microflex spectrometer (Bruker Daltonics, Leipzig, Germany) with a MTP 96 MALDI-TOF target plate (Bruker). The obtained spectra for a colony are imported into the MALDI BioTyper software (version 2.0, Bruker) and analyzed by standard pattern matching (with default parameter settings) against the 7567 references contained in our database (Bruker database incremented with our data). An identification score was obtained: a score $\geq 1.9$ allowed an identification at the species level; a score between 1.9 and 1.7 allowed identification only at the genus level and finally a score $<1.7$ gave no identification.

\subsection{Strain identification by $16 S$ rRNA sequencing}

Due to an identification of $<1.7$ for the MALDI-TOF MS analysis, the 16S rRNA gene was sequenced using fD1 and rP2 primers as previously described [20]. Stackebrandt and Ebers [21] determined a 98.65\% similarity level threshold to define a new species without performing DNA-DNA hybridization.

\subsection{Genomic DNA preparation}

Strain $\mathrm{mt}^{\mathrm{T}} \mathrm{T}^{\mathrm{T}}$ was cultured on $5 \%$ sheep blood-enriched Columbia agar (BioMerieux) at $37{ }^{\circ} \mathrm{C}$ anaerobically. Bacteria grown on three Petri dishes were resuspended in $400 \mu \mathrm{L}$ of TE buffer. Then, $200 \mu \mathrm{L}$ of this suspension was diluted in $1 \mathrm{mLTE}$ buffer for lysis treatment that included a 30- minute incubation with $2.5 \mu \mathrm{g} / \mu \mathrm{L}$ lysozyme at $37^{\circ} \mathrm{C}$, followed by an overnight incubation with $20 \mu \mathrm{g} / \mu \mathrm{L}$ proteinase $\mathrm{K}$ at $37{ }^{\circ} \mathrm{C}$. Extracted DNA was then purified using 3 successive phenol-chloroform extractions and ethanol precipitations at $-20^{\circ} \mathrm{C}$ overnight. After centrifugation, the DNA was resuspended in $160 \mu \mathrm{L}$ TE buffer. 


\subsection{Genome sequencing and assembly}

Genomic DNA (gDNA) of strain mt16 was sequenced on the MiSeq Technology (Illumina Inc, San Diego, CA, USA) with the mate pair strategy. The gDNA was barcoded in order to be mixed with 11 other projects with the Nextera Mate Pair sample prep kit (Illumina). gDNA was quantified by a Qubit assay with the high sensitivity kit (Thermo Fisher Scientific, Waltham, Massachusetts, USA) to $66.2 \mathrm{ng} / \mu \mathrm{l}$. The mate pair library was prepared with $1 \mu \mathrm{g}$ of gDNA using the Nextera mate pair Illumina guide. The gDNA sample was simultaneously fragmented and tagged (tagmentation) with a mate pair junction adapter. The pattern of the fragmentation was validated on an Agilent 2100 BioAnalyzer (Agilent Technologies Inc, Santa Clara, CA, USA) with a DNA 7500 labchip. The DNA fragments ranged in size from $1 \mathrm{~kb}$ up to $11 \mathrm{~kb}$ with an optimal size at $3.927 \mathrm{~kb}$. No size selection was performed and $505 \mathrm{ng}$ of tagmented fragments were circularized. The circularized DNA was mechanically sheared to small fragments with an optimal length at $597 \mathrm{bp}$ on the Covaris device S2 in microtubes (Covaris, Woburn, MA, USA). The library profile was visualized on a High Sensitivity Bioanalyzer LabChip (Agilent Technologies Inc, Santa Clara, CA, USA) and the final concentration library was measured at $59.2 \mathrm{nmol} / \mathrm{l}$. The libraries were normalized at $2 \mathrm{nM}$ and pooled. After a denaturation step and dilution at $15 \mathrm{pM}$, the pool of libraries was loaded onto the reagent cartridge and then onto the instrument along with the flow cell. An automated cluster generation and sequencing run was performed in a single $39-\mathrm{h}$ run in a $2 \times 251$-bp.

\subsection{Genome annotation and analysis}

Open Reading Frames (ORFs) were predicted using Prodigal [22] with default parameters but the predicted ORFs were excluded if they were spanning a sequencing gap region (contain $\mathrm{N}$ ). The predicted bacterial protein sequences were searched against the Clusters of Orthologous Groups (COG) using BLASTP (E-value $1 \mathrm{e}^{-03}$, coverage 0.7 and identity percent $30 \%$ ). If no hit was found, it was searched against the NR database using BLASTP with E-value of $1 \mathrm{e}^{-03}$ coverage 0,7 and identity percent of $30 \%$, and if the sequence length was smaller than 80 amino acids we used an E-value of $1 \mathrm{e}^{-05}$. The tRNAScanSE tool [23] was used to find tRNA genes, whereas ribosomal RNAs were found by using RNAmmer [24]. Lipoprotein signal peptides and the number of transmembrane helices were predicted using Phobius [25]. ORFans were identified if all the BLASTP performed did not give positive results ( $E$-value smaller than $1 \mathrm{e}^{-03}$ for ORFs with sequence size larger than 80 aa or $E$-value smaller than $1 \mathrm{e}^{-05}$ for ORFs with sequence length smaller 80 aа).

Genomes were automatically retrieved from the 16S RNA tree using XEGEN software (Phylopattern) [26]. For each selected genome, the complete genome sequence, proteome genome sequence (all gene sequences encoding proteins in a genome) and Orfeome genome sequence (all gene sequences encoding orphan proteins in a genome) were retrieved from the FTP of NCBI. All proteomes were analyzed with proteinOrtho [27]. Then for each couple of genomes, a similarity score was computed. This score is the mean value of nucleotide similarity between all couples of orthologues between the two genomes studied (AGIOS) [28]. An annotation of the entire proteome was performed to define the distribution of functional classes of predicted genes according to the clusters of orthologous groups of proteins (using the same method as for the genome annotation). To evaluate the genomic similarity among studied Anaerococcus strains, we determined two parameters; dDDH, which exhibits a high correlation with DDH $[29,30]$, and AGIOS [28], which was designed to be independent from $\mathrm{DDH}$. dDDH was determined using the Genome-to-Genome
Distance Calculator (GGDC) server (http://ggdc.dsmz.de/distcalc2. php). Genomes were aligned by the GGDC 2.0 Blast + method and results were interpreted with the formula 2 as recommended [30]. Annotation and comparison processes were performed in the Multi-Agent software system DAGOBAH [31] that include Figenix [32] libraries to provide pipeline analysis.

\section{Results}

\subsection{Phenotypic description}

Growth was observed at 28,37 and $45{ }^{\circ} \mathrm{C}$ in anaerobic atmosphere. Ideal growth was observed after $48 \mathrm{~h}$ at $37^{\circ} \mathrm{C}$ in anaerobic atmosphere. No growth occurred in aerobic and microaerophilic conditions. Non-sporeforming and non-motile cells formed small and white colonies with a mean diameter of $2 \mathrm{~mm}$. Gram-staining showed Gram-positive cocci (Fig. 1). Negative staining of strain mt16 observed in electron microscopy showed cocci arranged in pairs with a mean diameter $0.9 \mu \mathrm{m}$ (Fig. 2).

No oxidase activity was exhibited. Nevertheless, a positive catalase activity was observed for strain mt16. An API ZYM strip also showed positive activity for other enzymes: alkaline phosphatase, leucine arylamidase, valine arylamidase, acid phosphatase and Naphthol-AS-BI-phosphohydrolase. No activity was found for the following enzymes: esterase (C4), lipase esterase (C8), lipase (C14), cysteine arylamidase, trypsin, $\alpha$-chymotrypsin, $\alpha$-galactosidase, $\beta$-galactosidase, $\beta$-glucuronidase, $\alpha$-glucosidase, $\beta$-glucosidase, $\quad N$-acetyl- $\beta$-glucosaminidase, $\alpha$-mannosidase and $\alpha$ fucosidase. Nitrate reductase and nitrite reductase activities were absent according to the API 20A strip. Using an API 20A strip, indole formation was positive and acid was produced from D-glucose, Dsucrose, D-maltose and D-mannose. No acid production was observed from D-lactose, D-salicine, D-xylose, L-arabinose, glycerol, D-cellobiose, D-melezitose, D-raffinose, D-sorbitol, L-rhamnose and D-trehalose. Urease, $\beta$-glucosidase and protease activities were absent. An API $50 \mathrm{CH}$ also showed the metabolism of the following carbohydrates: tagatose and potassium-5-ketogluconate. The other carbohydrates sampled in the $50 \mathrm{CH}$ strip were not metabolized by strain mt16: glycerol, erythritol, D-arabinose, L-arabinose, D-ribose, D-xylose, L-xylose, D-adonitol, methyl- $\beta$ D-xylopyranoside, D-galactose, D-glucose, D-fructose, D-mannose, L-sorbose, L-rhamnose, dulcitol, inositol, D-mannitol, D-sorbitol, methyl- $\alpha \mathrm{D}-$ mannopyranoside, methyl- $\alpha \mathrm{D}$-glucopyranoside, amygdalin, arbutin, esculin ferric citrate, salicin, D-cellobiose, D-maltose, D-lactose, D-melibiose, Dsucrose, D-trehalose, inulin, D-melezitose, D-raffinose, starch, glycogen, xylitol, gentiobiose, D-turanose, D-lyxose, D-fucose, Lfucose, D-arabitol, L-arabitol, potassium gluconate and potassium 2ketogluconate.

The most abundant fatty acid was hexadecanoic acid (53\%).

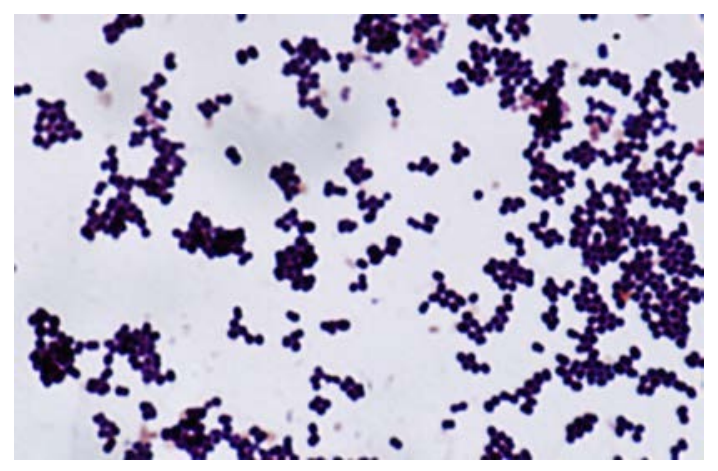

Fig. 1. Gram staining. Gram staining of Anaerococcus rubiinfantis strain $\mathrm{mt} 16^{\mathrm{T}}$. 


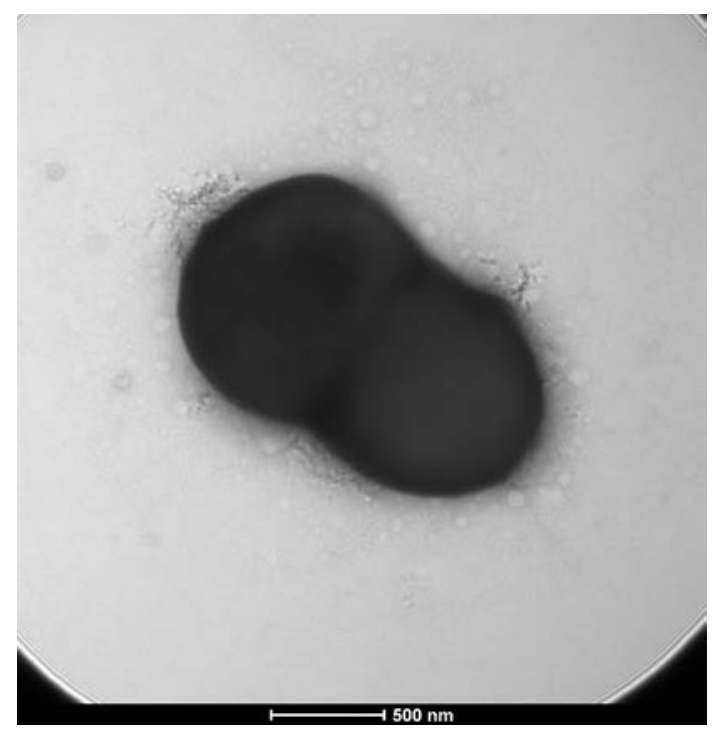

Fig. 2. Transmission electron microscopy. Transmission electron microscopy of Anaerococcus rubiifantis strain $\mathrm{mt}^{\mathrm{T}} 6^{\mathrm{T}}$ using a Tecnai G20 transmission electron microscope (FEI Company). The scale bar represents $500 \mathrm{~nm}$.

Unsaturated fatty acids 13-octadecenoic and 9,12-octadecadienoic were also measured with significant quantities. Minor amounts of other, mainly saturated, fatty acids, were also detected (Table 1). The comparison to other Anaerococcus species showed a relative similarity in the fatty acid profiles with 16:0 being the major fatty acid except in A. murdochii (major fatty acid: 18:1n9). All compared Anaeroccoccus species present core abundant fatty acids that are 16:0, 18:1n9, 18:2n6, 18:0 and 14:0 (Table 1).

Strain mt16 was susceptible to benzylpenicillin (MIC $<0.002 \mu \mathrm{g}$ / $\mathrm{mL}$ ), amoxicillin (MIC $<0.016 \mu \mathrm{g} / \mathrm{mL}$ ), amoxicillin/clavulanic acid (MIC $<0.016 \mu \mathrm{g} / \mathrm{mL}$ ), clindamycin ( $\mathrm{MIC}<0.023 \mu \mathrm{g} / \mathrm{mL}$ ), imipenem (MIC $<0.002 \mu \mathrm{g} / \mathrm{mL}$ ), metronidazole (MIC $<0.016 \mu \mathrm{g} / \mathrm{mL}$ ) and vancomycin ( $\mathrm{MIC}<0.016 \mu \mathrm{g} / \mathrm{mL}$ ). For Escherichia coli strain DSM 1103 which was used as a quality control strain, the following MICs $(4,4,0.125 \mu \mathrm{g} / \mathrm{mL})$ were obtained for amoxicillin, amoxicillin/ clavulanic acid and imipenem respectively. For this quality control strain, no growth inhibition was observed with the following antibiotics: benzylpenicillin, clindamycin, metronidazole and vancomycin.

\subsection{Strain identification by MALDI-TOF MS}

Strain mt16 was first isolated in April 2015 after a 10 days' anaerobic pre-incubation in liquid Colombia broth supplemented with $5 \%$ sheep blood at $37{ }^{\circ} \mathrm{C}$. The liquid culture was then inoculated on 5\% sheep blood Colombia agar (BioMerieux) and incubated in anaerobic condition at $37{ }^{\circ} \mathrm{C}$. According to the MALDI-TOF analysis, strain mt16's highest match was $A$. vaginalis with a score of 1.575 . This score under 1.7 did not allow the identification of strain mt16 at the species nor at the genus level and suggested that the closest species might be $A$. vaginalis. Strain $\mathrm{mt} 16$ was deposited on a MTP 96 target plate twelve times and the reference spectra obtained (Fig. 3) were incremented into our database. The spectrum of strain mt16 was also compared to other Anaerococcus species as represented in Fig. 4. The intensity of the peaks corresponding to strain mt16 was generally lower than that of compared Anaerococcus species, including its closest species, A. vaginalis.

\subsection{Strain identification by $16 S$ rRNA sequencing}

In order to identify strain mt16, the 16S rRNA gene was sequenced and the obtained sequence (Accession number LN881592) showed a $97.9 \%$ similarity level with $A$. vaginalis strain CCUG $31349^{\mathrm{T}}$ (Accession number AF542229.1), the phylogenetically closest validated species (Fig. 5). The general characteristics of strain $\mathrm{mt} 16^{\mathrm{T}}$ are presented in Table 2 . According to the similarity level threshold defined by Stackebrandt and Ebers [20], we propose strain $\mathrm{mt} 16^{\mathrm{T}}$ as the type strain of a new species within the Anaerococcus genus for which we suggest the name Anaerococcus rubiinfantis sp. nov.

\subsection{Genome properties}

Strain mt16 ${ }^{\mathrm{T}} \mathrm{s}$ genome (Accession number FAVH00000000) is $1,929,161$ bp with a $29.5 \% \mathrm{G}+\mathrm{C}$ content (Table 3, Fig. 6). At the final stage of assembly, it is composed of 3 scaffolds (composed of 5 contigs). There were 1864 predicted genes including 1808 proteincoding genes and 56 RNA genes. Among the RNA genes, there were 35 rRNA genes, 2 23S rRNA genes, a unique 16s rRNA gene and 50 tRNA genes. A putative function was assigned by COGS or NR blast to 1427 genes. 41 genes were identified as ORFans and the

Table 1

Cellular fatty acid profiles (\%) of Anaerococcus rubiinfantis strain mt16 compared with other Anaerococcus species.

\begin{tabular}{|c|c|c|c|c|c|c|c|}
\hline Fatty acids & Name & A. rubiinfantis & A. vaginalis $^{a}$ & A. senegalensis ${ }^{a}$ & A. tetradius ${ }^{a}$ & A. octavius $^{a}$ & A. murdochii $^{a}$ \\
\hline 5:0 anteiso & 2-methyl-butanoic acid & $\mathrm{TR}$ & ND & ND & ND & ND & ND \\
\hline $5: 0$ iso & 3-methyl-butanoic acid & ND & ND & ND & ND & $9.0 \pm 1.6$ & ND \\
\hline $10: 0$ & Decanoic acid & ND & $1.2 \pm 0.2$ & TR & TR & ND & ND \\
\hline $12: 0$ & Dodecanoic acid & $\mathrm{TR}$ & TR & $\mathrm{TR}$ & TR & $\mathrm{TR}$ & $\mathrm{TR}$ \\
\hline $14: 0$ & Tetradecanoic acid & $2.1 \pm 0.03$ & $6.9 \pm 0.2$ & $4.4 \pm 0.2$ & $2.7 \pm 0.1$ & $4.1 \pm 0.2$ & $1.9 \pm 0.0$ \\
\hline $15: 0$ & Pentadecanoic acid & $\mathrm{TR}$ & $1.0 \pm 0.1$ & $\mathrm{TR}$ & $\mathrm{TR}$ & $\mathrm{TR}$ & $\mathrm{TR}$ \\
\hline $16: 0$ & Hexadecanoic acid & $52.7 \pm 0.4$ & $59.2 \pm 1.1$ & $54.6 \pm 0.3$ & $35.7 \pm 1.2$ & $49.6 \pm 0.6$ & $28.6 \pm 0.2$ \\
\hline $16: 1 \mathrm{n} 7$ & 9-Hexadecenoic acid & $1.1 \pm 0.1$ & TR & ND & TR & ND & ND \\
\hline $17: 0$ & Heptadecanoic acid & $\mathrm{TR}$ & ND & TR & TR & ND & TR \\
\hline 17:0 anteiso & 14-methyl-Hexadecanoic acid & ND & ND & ND & TR & ND & ND \\
\hline $18: 0$ & Octadecanoic acid & $3.6 \pm 0.3$ & $5.7 \pm 0.4$ & $11.5 \pm 1.4$ & $16.7 \pm 0.3$ & $9.2 \pm 0.3$ & $13.4 \pm 0.4$ \\
\hline $18: 1 \mathrm{n} 6$ & 12-Octadecenoic acid & ND & ND & TR & $1.9 \pm 0.2$ & ND & $1.9 \pm 0.1$ \\
\hline 18:1n7 & 11-Octadecenoic acid & ND & ND & ND & $1.0 \pm 0.3$ & ND & TR \\
\hline $18: 1 n 9$ & 9-Octadecenoic acid & $28.2 \pm 0.04$ & $18.8 \pm 0.8$ & $17.6 \pm 0.7$ & $29.9 \pm 0.5$ & $23.5 \pm 1.4$ & $35.9 \pm 0.3$ \\
\hline $18: 2 n 6$ & 9,12-Octadecadienoic acid & $10.1 \pm 0.5$ & $6.5 \pm 0.3$ & $9.2 \pm 0.6$ & $11.0 \pm 0.2$ & $3.8 \pm 0.3$ & $17.0 \pm 0.7$ \\
\hline $20: 4 n 6$ & 5,8,11,14-Eicosatetraenoic acid & ND & ND & ND & ND & ND & $\mathrm{TR}$ \\
\hline
\end{tabular}

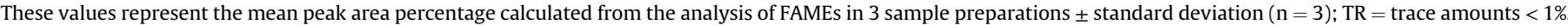
Bold represents the majority fatty acid for this species.

a These strains are provided by the Collection des Souches de l'Unité des Rickettsies (CSUR). 


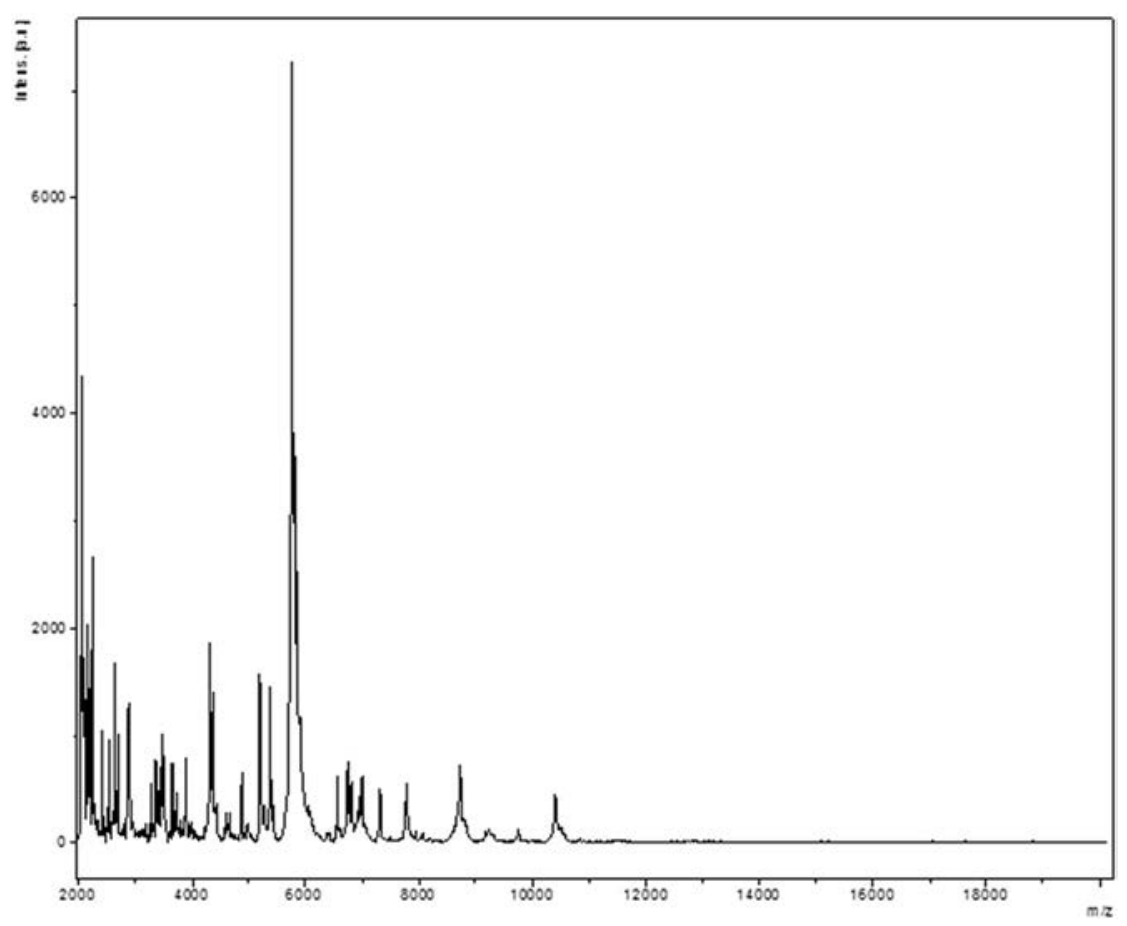

Fig. 3. Reference mass spectrum from Anaerococcus rubiinfantis strain $\mathrm{mt} 16^{\mathrm{T}}$. Spectra from 12 individual colonies were compared and a reference spectrum was generated.

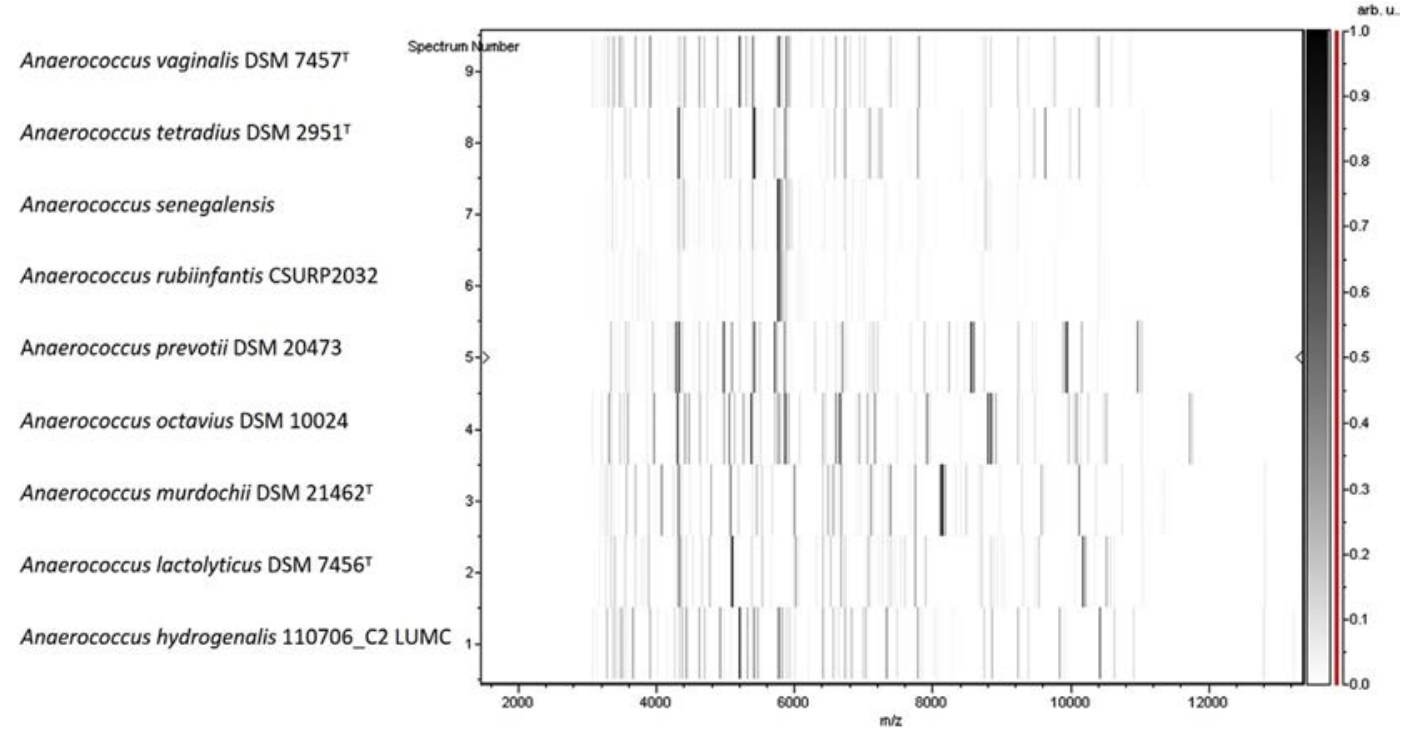

Fig. 4. MALDI-TOF MS comparative analysis of Anaerococcus species. Gel view comparing Anaerococcus rubiinfantis strain mt $16^{\mathrm{T}}$ to other species within the Anaerococcus genus. The gel view displays the raw spectra of loaded spectrum files arranged in a pseudo-gel like look. The $\mathrm{x}$-axis records the $\mathrm{m} / \mathrm{z}$ value. The left $\mathrm{y}$-axis displays the running spectrum number originating from subsequent spectra loading. The peak intensity is expressed by a Gray scale scheme code. The right y-axis indicates the relation between the color of a peak and its intensity, in arbitrary units. Displayed species are indicated on the left.

remaining 274 genes were identified as encoding hypothetical proteins. The gene distribution into COG functional categories is reported in Table 4.

\subsection{Genome comparison}

Strain mt16 genomic characteristics were compared to the characteristics of closely related species (Table 5).

The size of the draft genome sequence of strain mt16 (1.93 MB) is smaller than those of A. prevotii (2 MB), A. tetradius (2.10 MB) and
Anaerococcus lactolyticus (2.18 MB) but larger than the genomes of Peptoniphilus harei (1.84 MB), Anaerococcus hydrogenalis (1.89 MB) and $A$. vaginalis (1.87 MB). The $\mathrm{G}+\mathrm{C}$ content of strain $\mathrm{mt} 16(29.45 \%)$ is smaller than most of the compared genomes: P. harei (34.44\%), A. tetradius (34.15\%), A. hydrogenalis (29.64\%), A. prevotii (35.64\%) and A. lactolyticus (34.94\%). Only A. vaginalis G + C content (28.87\%) is smaller than that of strain $\mathrm{mt} 16$.

The gene content of strain $\mathrm{mt} 16$ is larger than $P$. harei, A. vaginalis and A. prevotii's gene contents (1,724, 1764 and 1806 respectively) but smaller than $A$. tetradius, A. hydrogenalis and 


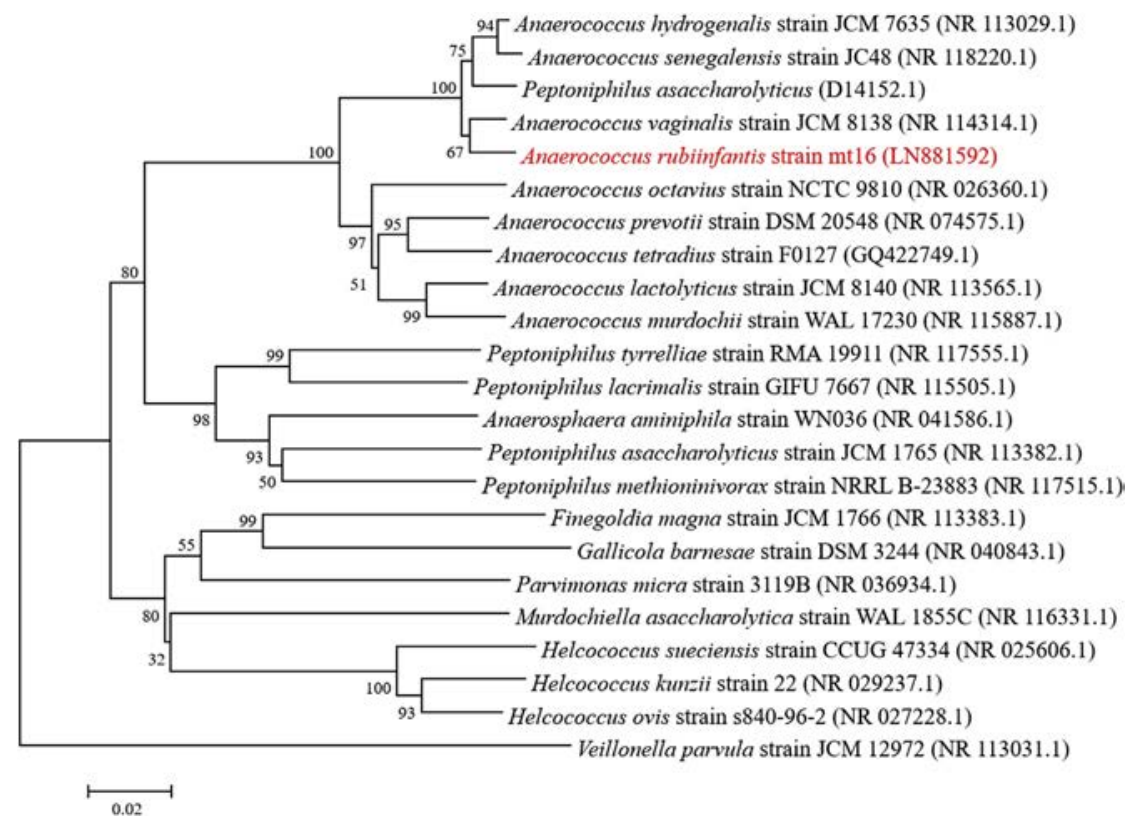

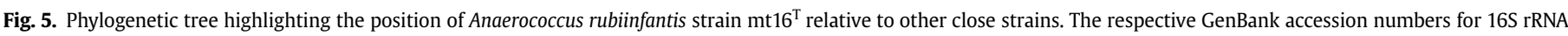

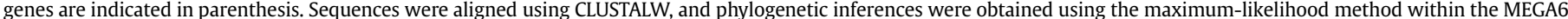

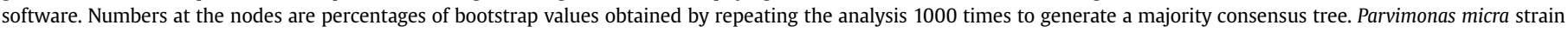
3119B was used as an outgroup. The scale bar represents a $1 \%$ nucleotide sequence divergence.

Table 2

Classification and general features of Anaerococcus rubiinfantis strain $\mathrm{mt} 16^{\mathrm{T}}$.

\begin{tabular}{ll}
\hline Property & Term \\
\hline Current classification & Domain: Bacteria \\
& Phylum: Firmicutes \\
& Class: Tissierellia \\
& Order: Tissierellales \\
& Family: Peptoniphilaceae \\
& Genus: Anaerococcus \\
& Species: Anaerococcus rubiinfantis \\
& Type strain: mt16 \\
Gram stain & Positive \\
Cell shape & Cocci \\
Motility & Non-motile \\
Sporulation & Non-sporulating \\
Temperature range & Mesophilic \\
Optimum temperature & $37{ }^{\circ} \mathrm{C}$ \\
\hline
\end{tabular}

Table 3

Nucleotide content and gene count levels of the genome.

\begin{tabular}{llc}
\hline Attribute & \multicolumn{2}{l}{ Genome (total) } \\
\cline { 2 - 3 } & Value & \% of total \\
\hline Size (bp) & $1,929,161$ & 100 \\
G + C content (\%) & 568,166 & 29.45 \\
Coding region (bp) & $1,737,861$ & 90.08 \\
Total genes (total ORFs) & 1864 & 100 \\
RNA genes & 56 & 3 \\
Protein-coding genes & 1808 & 97 \\
Genes with function prediction & 1427 & 78.9 \\
Genes assigned to COGs & 1243 & 68.75 \\
Genes with signal peptides & 163 & 9.01 \\
Genes with transmembrane helices & 412 & 22.78 \\
ORFan genes & 41 & 2.26 \\
Genes associated with PKS or NRPS & 2 & 0.11 \\
$\mathrm{~N}^{\mathrm{o}}$ of antibiotic resistance genes & 0 & 0 \\
\hline
\end{tabular}

a The total is based on either the size of the genome in base pairs or the total number of protein coding genes in the annotated genome.

b PKS: Polyketide Synthase; NRPS: Non-Ribosomal Peptide Synthase.

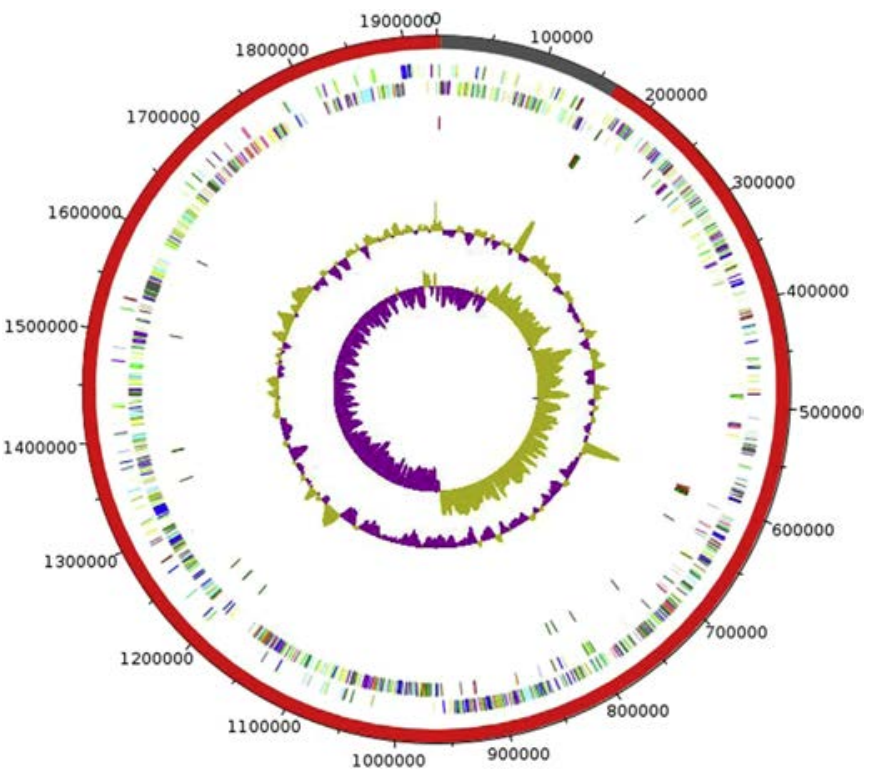

Fig. 6. Graphical circular map of the chromosome. From outside to the center: Contigs (red/grey), genes on the forward strand colored by COG categories (only gene assigned to $C O G$ ), RNA genes (tRNAs green, rRNAs red) $G+C$ content and $G+C$ skew (purple: value below the mean, yellow: value above the mean). (For interpretation of the references to color in this figure legend, the reader is referred to the web version of this article.)

A. lactolyticus's gene contents (2,079, 2069 and 2253 respectively).

The distribution of genes into COG categories was similar in all compared genomes except for the carbohydrates metabolism and transport for P. harei, for which this function is reduced (Fig. 7). Strain mt16 shared 1,003, 738, 1,061, 1,073, 1188 and 1091 orthologous genes with $A$. lactolyticus, $P$. harei, A. tetradius, A. hydrogenalis, A. vaginalis and $A$. prevotii respectively (Table 6 ). Among species with standing in nomenclature, AGIOS values ranged from 58 to 
Table 4

Number of genes associated with the 25 general COG functional categories.

\begin{tabular}{|c|c|c|c|}
\hline Code & Value & $\%$ of total ${ }^{\mathrm{a}}$ & Description \\
\hline [J] & 167 & 9.23 & Translation \\
\hline$[\mathrm{A}]$ & 0 & 0 & Rna processing and modification \\
\hline$[\mathrm{K}]$ & 90 & 4.97 & Transcription \\
\hline [L] & 63 & 3.48 & Replication, recombination and repair \\
\hline [B] & 0 & 0 & Chromatin structure and dynamics \\
\hline [D] & 19 & 1.05 & Cell cycle control, mitosis and meiosis \\
\hline [Y] & 0 & 0 & Nuclear structure \\
\hline [V] & 43 & 2.37 & Defense mechanisms \\
\hline [T] & 47 & 2.59 & Signal transduction mechanisms \\
\hline [M] & 58 & 3.20 & Cell wall/membrane biogenesis \\
\hline$[\mathrm{N}]$ & 5 & 0.27 & Cell motility \\
\hline [Z] & 0 & 0 & Cytoskeleton \\
\hline [W] & 3 & 0.16 & Extracellular structures \\
\hline [U] & 16 & 0.88 & Intracellular trafficking and secretion \\
\hline [0] & 57 & 3.15 & Posttanslational modification, protein turnover,chaperones \\
\hline$[\mathrm{X}]$ & 20 & 1.10 & Mobilome: prophages, transposons \\
\hline [C] & 88 & 4.86 & Energy production and conversion \\
\hline$[G]$ & 106 & 5.86 & Carbohydrate transport and metabolism \\
\hline [E] & 121 & 6.69 & Amino acid transport and metabolism \\
\hline [F] & 62 & 3.43 & Nucleotide transport and metabolism \\
\hline$[\mathrm{H}]$ & 77 & 4.26 & Coenzyme transport and metabolism \\
\hline [I] & 33 & 1.82 & Lipid transport and metabolism \\
\hline [P] & 79 & 4.37 & Inorganic ion transport and metabolism \\
\hline [Q] & 14 & 0.77 & Secondary metabolites biosynthesis, transport and catabolism \\
\hline$[\mathrm{R}]$ & 121 & 6.69 & General function prediction only \\
\hline [S] & 66 & 3.65 & Function unknown \\
\hline- & 565 & 31.25 & Not in COGs \\
\hline
\end{tabular}

a The total is based on the total number of protein coding genes in the annotated genome.

Table 5

Genome comparison of closely related species to Anaerococcus rubiinfantis strain $\mathrm{mt} 16^{\mathrm{T}}$.

\begin{tabular}{|c|c|c|c|c|c|}
\hline Name of organisms & INSDC identifier $^{\mathrm{a}}$ & Size $(\mathrm{Mb})$ & $G+C(\%)$ & Protein coding genes & Total genes (total ORFs) \\
\hline $\begin{array}{l}\text { Anaerococcus rubiifantis } \\
\text { Strain } \mathrm{mt} 16^{\mathrm{T}}\end{array}$ & FAVH00000000 & 1.92 & 29.45 & 1808 & 1864 \\
\hline $\begin{array}{l}\text { Anaerococcus hydrogenalis } \\
\text { DSM } 7454\end{array}$ & ABXA00000000 & 1.89 & 29.64 & & 2069 \\
\hline $\begin{array}{l}\text { Anaerococcus vaginalis } \\
\text { ATCC } 51170\end{array}$ & ACXU00000000.1 & 1.87 & 28.87 & & 1764 \\
\hline $\begin{array}{l}\text { Peptoniphilus harei } \\
\text { ACS-146-V-Sch2b }\end{array}$ & AENP00000000.1 & 1.84 & 34.44 & & 1724 \\
\hline $\begin{array}{l}\text { Anaerococcus lactolyticus } \\
\text { ATCC } 51172\end{array}$ & JRMW00000000.1 & 2.18 & 34.94 & & 2253 \\
\hline $\begin{array}{l}\text { Anaerococcus prevotii } \\
\text { DSM } 20548\end{array}$ & СР001708.1 & 2.00 & 35.64 & & 1806 \\
\hline $\begin{array}{l}\text { Anaerococcus tetradius } \\
\text { ATCC } 35098\end{array}$ & ACGC00000000.1 & 2.10 & 34.15 & & 2079 \\
\hline
\end{tabular}

${ }^{a}$ INSDC: International Nucleotide Sequence Database Collaboration.

$79 \%$ among compared species except strain $\mathrm{mt} 16$. When comparing strain mt 16 to other species, the AGIOS value ranged from $65 \%$ with $P$. harei to $88 \%$ with $A$. vaginalis (Table 6 ). dDDH values estimated between strain $\mathrm{mt} 16^{\mathrm{T}}$ and the compared genomes ranged from $18.8 \%$ to $34.7 \%$. Well under $70 \%$, these values confirm strain $\mathrm{mt} 16^{\mathrm{T}}$ as a new species [30].

\subsection{Comparison with other Anaerococcus species}

The characteristics of strain mt16 were compared to the characteristics of closely related Anaerococcus species. Differences were observed for several characteristics such as cell diameter, indole production, enzymes production, acid production from carbohydrates, $\mathrm{G}+\mathrm{C}$ content, and habitat as reported in Table 7.

\section{Discussion}

Strain $\mathrm{mt} 16^{\mathrm{T}}$ was isolated from the stool sample of an 8-month old infant afflicted with kwashiorkor. Phenotypic characterization, MALDI-TOF MS, 16S rRNA sequencing, and comparative genomic analyses among close phylogenetic relatives allowed identification of strain $\mathrm{mt} 16^{\mathrm{T}}$ as a new species within the genus Anaerococcus, with closest relative being $A$. vaginalis. However, several discrepancies with $A$. vaginalis including a $16 \mathrm{~S}$ rRNA similarity, low dDDH and low AGIOS values confirmed it as a new species.

Typical features of the present strain included a susceptibility to all tested antibiotics consistent with the absence of known antibiotic resistance genes (Table 4). This high antibiotic susceptibility is clinically relevant and suggesting that gut Anaerococcus species could be altered by oral antibiotics. Further studies are needed to determine whether Anaerococcus rubiinfantis, found in this study in a severely malnourished child, is part of the Healthy Mature Anaerobic Gut Microbiota [3], is associated with malnutrition, or has no role on nutritional status. Moreover, future studies should elucidate if gut symbionts resistant to commonly used antibiotics are more likely to be pathogenic, such as Clostridium difficile 


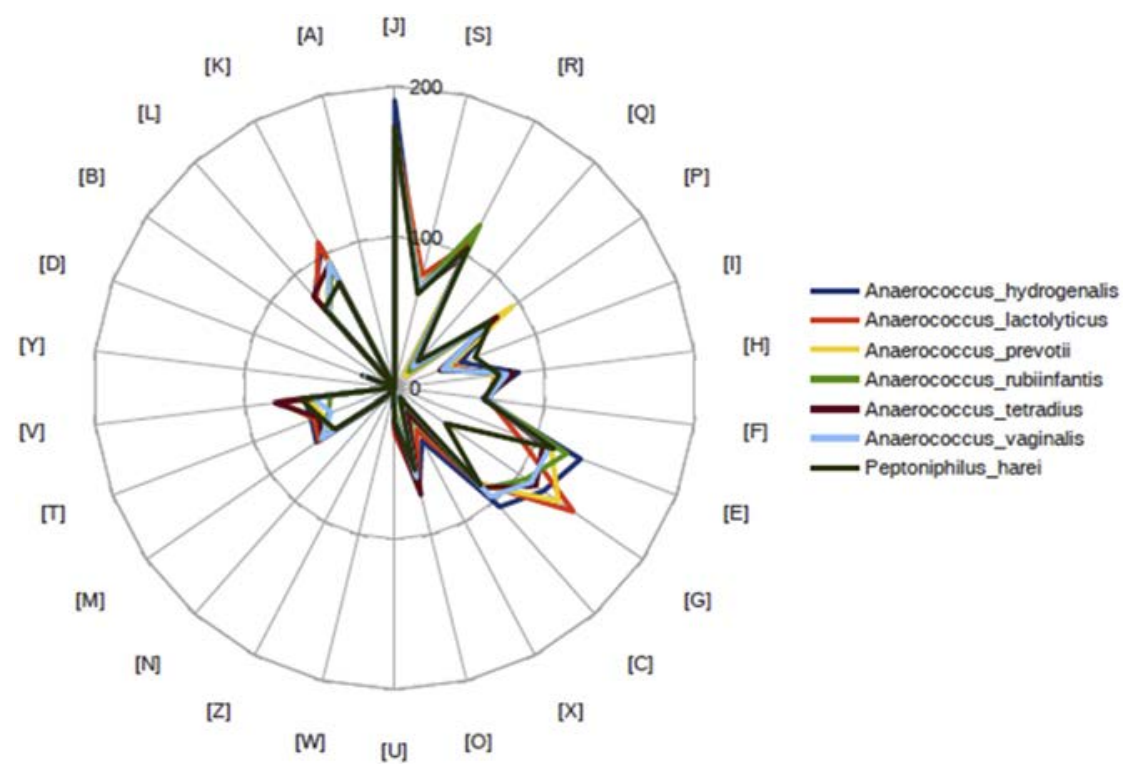

Fig. 7. Distribution of functional classes of predicted genes according to the clusters of orthologous groups of protein. For the codes of COG categories, see Table 4.

Table 6

The number of orthologous proteins shared between genomes (upper right) ${ }^{\mathrm{a}}$.

\begin{tabular}{|c|c|c|c|c|c|c|c|}
\hline & $\begin{array}{l}\text { Anaerococcus } \\
\text { lactolyticus }\end{array}$ & $\begin{array}{l}\text { Peptoniphilus } \\
\text { harei }\end{array}$ & $\begin{array}{l}\text { Anaerococcus } \\
\text { tetradius }\end{array}$ & $\begin{array}{l}\text { Anaerococcus } \\
\text { hydrogenalis }\end{array}$ & $\begin{array}{l}\text { Anaerococcus } \\
\text { rubiinfantis }\end{array}$ & $\begin{array}{l}\text { Anaerococcus } \\
\text { vaginalis }\end{array}$ & $\begin{array}{l}\text { Anaerococcus } \\
\text { prevotii }\end{array}$ \\
\hline A. lactolyticus & 2253 & 727 & 1145 & 938 & 1003 & 1047 & 1108 \\
\hline P. harei & 0.65 & 1724 & 752 & 677 & 738 & 753 & 733 \\
\hline A. tetradius & 0.73 & 0.65 & 2079 & 980 & 1061 & 1111 & 1193 \\
\hline A.hydrogenalis & 0.6 & 0.58 & 0.60 & 2069 & 1073 & 1083 & 989 \\
\hline A.rubiinfantis & 0.70 & 0.65 & 0.71 & 0.68 & 1808 & 1188 & 1091 \\
\hline A.vaginalis & 0.70 & 0.66 & 0.71 & 0.67 & 0.88 & 1764 & 1082 \\
\hline A.prevotii & 0.72 & 0.65 & 0.79 & 0.60 & 0.70 & 0.70 & 1806 \\
\hline
\end{tabular}

Bold represents the total number of orthologous proteins for this species.

${ }^{a}$ Average percentage similarity of nucleotides corresponding to orthologous proteins shared between genomes (lower left) and numbers of proteins per genome.

(antibiotic resistance by sporulation) and the aerotolerant Klebsiella oxytoca previously identified as a causative organism of antibioticassociated hemorrhagic colitis [33].

A paradoxical feature observed in our strain and several other Anaerococcus members (A. vaginalis, A. senegalensis, A. prevotii and some strains of A. tetradius and A. octavius - Table 7) was the presence of a catalase enzyme [34]. In fact, a catalase activity has been found in several strictly anaerobic species such as some members of the genera Bacteroides, Clostridium, Porphyromonas, Desulfovibrio and even few archaeal species [34]. This suggest a different oxidative stress resistance level among anaerobic prokaryotes. Indeed, while Methanobrevibacter smithii and Faecalibacterium prausnitzii are prokaryotes among the most sensitive ones to oxygen ( $F$. prausnitzii loses its viability within 2 min after exposure to ambient air [35]), we observed a trace but nonsignificant growth of $A$. rubiinfantis in microaerophilic conditions, as previously reported for $A$. senegalensis [12]. These results suggest that the aerobic/anaerobic bacterial culture dichotomy is no longer relevant [36] and that there is a continuum between species whose growth is not affected by a normal (ambient air) partial pressure of oxygen and/or positive redox potential, and species that only grow in total absence of oxygen and/or when redox potential is very low [37]. Moreover, tolerance to oxygen and to redox potential of the environment seems completely dependent on the presence of diverse antioxidants [36] and electron acceptors in the medium
[35]. This opens new perspectives for exploration in the field of the 'anaerobic' prokaryotes.

Finally, we confirmed the usefulness of genomic analysis as an updated tool to identify, classify and describe more accurately new bacterial strains as promoted by the taxonogenomics description concept [10]. Differences between strain mt16 and A. vaginalis (its closest neighbor) also included the production of alkaline phosphatase as well as the production of acids from the following carbohydrates: arabinose, mannitol and sucrose [38]. Strain mt16 was classified among the Anaerococcus genus that currently contains eight validated species [5] which are Gram-positive, strictly anaerobic, non-motile, and mostly non-sporeforming species $[6,12]$. The phylogenetic relationship between several members of the family Peptoniphilaceae to which the genus Anaerococcus belongs, displayed in Fig. 5, showed strain mt16 in the midst of the validated Anaerococcus species.

Given the phylogenetic analysis of the 16S rRNA gene sequence of strain $\mathrm{mt} 16^{\mathrm{T}}$, its proteomic profile obtained with MALDI-TOF MS, its genomic description and annotation and $\mathrm{dDDH}$ values, we thus defined strain $\mathrm{mt}^{1} 6^{\mathrm{T}}$ as a new species called Anaerococcus rubiinfantis sp. nov. (=CSUR P2032 = DSM 101186).

Taxonomic and nomenclatural proposals Description of Anaerococcus rubiinfantis strain $\mathrm{mt}^{\mathrm{T}}{ }^{\mathrm{T}} \mathrm{sp}$. nov. (from ru.be.us (adj) infantis (L. gen. n.) meaning of a red infant, which is a reference to the hair discoloration observed in kwashiorkor patients). 
Table 7

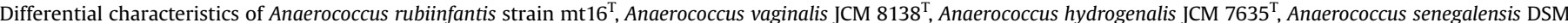

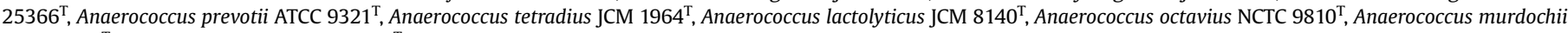
ATCC-1385 ${ }^{\mathrm{T}}$, Bacillus sonorensis DSM $13779^{\mathrm{T}}[12,38-43]$.

\begin{tabular}{|c|c|c|c|c|c|c|c|c|c|}
\hline Properties & $\begin{array}{l}\text { Anaerococcus } \\
\text { rubiinfantis }^{\mathrm{a}}\end{array}$ & $\begin{array}{l}\text { Anaerococcus } \\
\text { vaginalis }^{\text {b }}\end{array}$ & $\begin{array}{l}\text { Anaerococcus } \\
\text { hydrogenalis }^{\mathrm{b}}\end{array}$ & $\begin{array}{l}\text { Anaerococcus } \\
\text { senegalensis }^{\text {a }}\end{array}$ & $\begin{array}{l}\text { Anaerococcus } \\
\text { prevotii }^{\text {b }}\end{array}$ & $\begin{array}{l}\text { Anaerococcus } \\
\text { tetradius }^{\text {b }}\end{array}$ & $\begin{array}{l}\text { Anaerococcus } \\
\text { lactolyticus }^{\mathrm{b}}\end{array}$ & $\begin{array}{l}\text { Anaerococcus } \\
\text { octavius }^{\text {b }}\end{array}$ & $\begin{array}{l}\text { Anaerococcus } \\
\text { murdochii }^{\text {b }}\end{array}$ \\
\hline $\begin{array}{l}\text { Cell diameter } \\
\quad(\mu \mathrm{m})\end{array}$ & 0.9 & na & $0.7-1.8$ & 0.87 & $0.7-1.8$ & $<1.8$ & na & $0.7-0.9$ & $\geq 0.7$ \\
\hline Indole & + & + & + & + & - & - & - & - & - \\
\hline $\begin{array}{l}\text { Major } \\
\quad \text { fatty acid }\end{array}$ & $16: 0$ & $16: 0$ & na & $16: 0$ & na & $16: 0$ & na & $16: 0$ & $18: 1 n 9$ \\
\hline $\begin{array}{l}G+C \text { content } \\
\quad(\%)\end{array}$ & 29.5 & $30-34$ & $30-34$ & 28.56 & $29-33$ & $30-32$ & $30-34$ & $26-31$ & na \\
\hline \multicolumn{10}{|l|}{ Production of } \\
\hline $\begin{array}{l}\text { Alkaline } \\
\text { phosphatase }\end{array}$ & + & - & - & + & - & - & - & - & + \\
\hline Catalase & + & na & - & + & + & \pm & na & \pm & - \\
\hline $\begin{array}{l}\text { Nitrate } \\
\quad \text { reductase }\end{array}$ & - & na & - & - & - & - & na & - & - \\
\hline Urease & - & - & \pm & + & \pm & + & + & - & - \\
\hline $\begin{array}{l}\beta \text {-galactosidase } \\
\text { Acid from }\end{array}$ & - & - & - & - & - & - & + & - & + \\
\hline L-Arabinose & + & - & na & - & - & - & - & - & na \\
\hline Ribose & - & na & na & + & + & - & - & - & na \\
\hline Mannose & + & \pm & + & + & + & + & + & + & + \\
\hline Mannitol & + & - & + & - & - & - & - & \pm & na \\
\hline Sucrose & + & - & - & + & - & + & - & - & na \\
\hline D-glucose & + & + & + & + & \pm & \pm & + & + & + \\
\hline D-fructose & - & na & - & + & $\mathrm{w}$ & + & na & - & na \\
\hline D-maltose & + & na & - & - & - & - & na & - & na \\
\hline D-lactose & - & - & + & - & - & - & + & - & - \\
\hline Habitat & Human gut & $\begin{array}{l}\text { Vaginal } \\
\text { discharges }\end{array}$ & $\begin{array}{l}\text { Vaginal } \\
\text { discharges }\end{array}$ & Human gut & $\begin{array}{l}\text { Clinical } \\
\text { specimens }\end{array}$ & $\begin{array}{l}\text { Vaginal } \\
\text { discharges }\end{array}$ & $\begin{array}{l}\text { Vaginal } \\
\text { discharges }\end{array}$ & Nasal cavity & $\begin{array}{l}\text { Clinical } \\
\text { specimens }\end{array}$ \\
\hline
\end{tabular}

na: non available data.

a Testing was realized in house for these species or this property.

b The test results reported in this table are provided by the literature except for the results for the major fatty acid.

The cells are Gram-positive, non-sporeforming, non-motile cocci with a diameter of $0.9 \mu \mathrm{m}$ that form small white colonies on $5 \%$ sheep-blood enriched Colombia agar with a mean diameter of $2 \mathrm{~mm}$. Strain $\mathrm{mt} 16^{\mathrm{T}}$ optimal growth is at $37^{\circ}$ under anaerobic atmosphere. The major fatty acid was hexadecanoic acid. Catalase positive. Oxidase negative. Positive reactions were observed for alkaline phosphatase, leucine arylamidase, valine arylamidase, $\beta$ glucosidase, acid phosphatase and Naphthol-AS-BIphosphohydrolase with an API ZYM strip. Neither urease nor nitrate reduction were observed. Indole was produced. Arabinose, glucose, sucrose, mannose, mannitol, tagatose, potassium-5ketogluconate, $\mathrm{N}$-acetyl-glucosamine, maltose, potassium gluconate, capric acid, adipic acid, trisodium citrate and phenylacetic acid were metabolized according to the API 50CH and API $20 \mathrm{~A}$ strips. D-lactose, D-salicine, D-xylose, glycerol, D-cellobiose, Dmelezitose, D-raffinose, D-sorbitol, L-rhamnose, D-trehalose, glycerol, erythritol, D-adonitol, methyl- $\beta \mathrm{D}-\mathrm{xylopyranoside,} \mathrm{D}$-fructose, $\mathrm{L}-$ sorbose, L-rhamnose, dulcitol, inositol, D-sorbitol, methyl- $\alpha \mathrm{D}-\mathrm{man}-$ nopyranoside, methyl- $\alpha$ D-glucopyranoside, amygdalin, arbutin, Dtrehalose, inulin, starch, glycogen, xylitol, gentiobiose, D-turanose, D-lyxose, D-lyxose, L-lyxose, D-arabitol, L-arabitol, D-fucose, L-fucose, potassium ketogluconate and potassium 2-gluconate were not metabolized. Strain mt16 was susceptible to amoxicillin, amoxicillin/clavulanic acid, benzylpenicillin, clindamycin, imipenem, metronidazole and vancomycin. The genome is $1,929,161 \mathrm{bp}$ long with a $29.5 \% \mathrm{G}+\mathrm{C}$ content and accessible under FAVH00000000 in the GenBank collection. The 16S rRNA sequence is also accessible in the GenBank collection under number LN881592. The type strain mt16 ${ }^{\mathrm{T}}$ (= CSUR P2032 = DSM 101186) was isolated from the stool of a child living in Senegal and suffering from kwashiorkor.

\section{Conflict of interest}

The authors declare no conflict of interest.

\section{Acknowledgements}

The authors thank the Xegen Company (www.xegen.fr) for automating the genomic annotation process. This study was funded by the Méditerranée Infection Foundation.

We thank Karolina Griffiths and Magdalen Lardiere for English reviewing.

\section{References}

[1] H. Wang, C.A. Liddell, M.M. Coates, M.D. Mooney, C.E. Levitz, A.E. Schumacher, et al., Murray, Global, regional, and national levels of neonatal, infant, and under-5 mortality during 1990-2013: a systematic analysis for the Global Burden of Disease Study 2013, Lancet 384 (2014) 957-979, http://dx.doi.org/ 10.1016/S0140-6736(14)60497-9.

[2] M. Million, M. Tidjani Alou, S. Khelaifia, D. Bachar, J-C. Lagier, N. Dione, et al. Increased gut redox and depletion of anaerobic and methanogenic prokaryotes in severe acute malnutrition, Sci. Rep. 6 (2016) 26051, http:// dx.doi.org/10.1038/srep26051.

[3] M. Million, A. Diallo, D. Raoult, Gut microbiota and malnutrition, Microb. Pathog. (2016), http://dx.doi.org/10.1016/j.micpath.2016.02.003.

[4] J.-C. Lagier, F. Armougom, M. Million, P. Hugon, I. Pagnier, C. Robert, et al., Microbial culturomics: paradigm shift in the human gut microbiome study, Clin. Microbiol. Infect. 18 (2012) 1185-1193, http://dx.doi.org/10.1111/14690691.12023.

[5] A.C. Parte, LPSN-list of prokaryotic names with standing in nomenclature, Nucleic Acids Res. 42 (2014) D613-D616, http://dx.doi.org/10.1093/nar/ gkt1111.

[6] P. De Vos, G.M. Garrity, D. Jones, N.R. Krieg, W. Ludwig, F.A. Rainey, et al., Bergey's Manual of Systematic Bacteriology, in: The Firmicutes, second ed., vol. 3, Springer-Verlag, New York, New York, 2009 http://dx.doi.org/10.1007/9780-387-68489-5.

[7] A.M. Viale, A.K. Arakaki, F.C. Soncini, R.G. Ferreyra, Evolutionary relationships 
among eubacterial groups as inferred from GroEL (chaperonin) sequence comparisons, Int. J. Syst. Bacteriol. 44 (1994) 527-533, http://dx.doi.org/ 10.1099/00207713-44-3-527.

[8] C.R. Woese, O. Kandler, M.L. Wheelis, Towards a natural system of organisms: proposal for the domains Archaea, Bacteria, and Eucarya, Proc. Natl. Acad. Sci. U. S. A. 87 (1990) 4576-4579.

[9] M. Wolf, T. Müller, T. Dandekar, J.D. Pollack, Phylogeny of Firmicutes with special reference to Mycoplasma (Mollicutes) as inferred from phosphoglycerate kinase amino acid sequence data, Int. J. Syst. Evol. Microbiol. 54 (2004) 871-875, http://dx.doi.org/10.1099/ijs.0.02868-0.

[10] P.-E. Fournier, J.-C. Lagier, G. Dubourg, D. Raoult, From culturomics to taxonomogenomics: a need to change the taxonomy of prokaryotes in clinical microbiology, Anaerobe 36 (2015) 73-78, http://dx.doi.org/10.1016/ j.anaerobe.2015.10.011.

[11] P. Seng, M. Drancourt, F. Gouriet, B. La Scola, P.-E. Fournier, J.M. Rolain, et al., Ongoing revolution in bacteriology: routine identification of bacteria by matrix-assisted laser desorption ionization time-of-flight mass spectrometry, Clin. Infect. Dis. 49 (2009) 543-551, http://dx.doi.org/10.1086/600885.

[12] J.-C. Lagier, K. El Karkouri, T.-T. Nguyen, F. Armougom, D. Raoult, P.E. Fournier, Non-contiguous finished genome sequence and description of Anaerococcus senegalensis sp. nov, Stand. Genom. Sci. 6 (2012) 116-125, http://dx.doi.org/10.4056/sigs.2415480.

[13] J.-C. Lagier, P. Hugon, S. Khelaifia, P.-E Fournier, B. La Scola, D. Raoult, The rebirth of culture in microbiology through the example of culturomics to study human gut microbiota, Clin. Microbiol. Rev. 28 (2015) 237-264, http:// dx.doi.org/10.1128/CMR.00014-14

[14] P.R. Murray, E.J. Baron, J.H. Jorgensen, M.L. Landry, M.A. Pfaller, Manual of Clinical Microbiology, ninth ed., ASM Press, Washington, D.C, 2007.

[15] M. Sasser, Bacterial Identification by Gas Chromatographic Analysis of Fatty Acids Methyl Esters (GC-FAME), http://www.midi-inc.com/pdf/MIS Technote_101.pdf (accessed 27.05.16).

[16] E. Matuschek, D.F.J. Brown, G. Kahlmeter, Development of the EUCAST disk diffusion antimicrobial susceptibility testing method and its implementation in routine microbiology laboratories, Clin. Microbiol. Infect. 20 (2014) O255-0266, http://dx.doi.org/10.1111/1469-0691.12373.

[17] D.M. Citron, M.I. Ostovari, A. Karlsson, E.J. Goldstein, Evaluation of the E test for susceptibility testing of anaerobic bacteria, J. Clin. Microbiol. 29 (1991) 2197-2203.

[18] The European Committee on Antimicrobial Susceptibility Testing, Breakpoint Tables for Interpretation of MICs and Zone Diameters. Version 6.0, 2016 http://www.eucast.org (accessed 22.05.16).

[19] P. Seng, C. Abat, J.M. Rolain, P. Colson, J.-C. Lagier, F. Gouriet, et al., Identification of rare pathogenic bacteria in a clinical microbiology laboratory: impact of matrix-assisted laser desorption ionization-time of flight mass spectrometry, J. Clin. Microbiol. 51 (2013) 2182-2194, http://dx.doi.org/ 10.1128/JCM.00492-13.

[20] M. Drancourt, C. Bollet, A. Carlioz, R. Martelin, J.P. Gayral, D. Raoult, 16S ribosomal DNA sequence analysis of a large collection of environmental and clinical unidentifiable bacterial isolates, J. Clin. Microbiol. 38 (2000) 3623-3630.

[21] E. Stackebrandt, J. Ebers, Taxonomic parameters revisited: tarnished gold standards, Microbiol. Today 33 (2006) 152.

[22] D. Hyatt, G.-L. Chen, P.F. Locascio, M.L. Land, F.W. Larimer, L.J. Hauser, Prodigal: prokaryotic gene recognition and translation initiation site identification, BMC Bioinforma. 11 (2010) 119, http://dx.doi.org/10.1186/1471-2105-11119.

[23] T.M. Lowe, S.R. Eddy, tRNAscan-SE: a program for improved detection of transfer RNA genes in genomic sequence, Nucleic Acids Res. 25 (1997) 955-964.

[24] K. Lagesen, P. Hallin, E.A. Rødland, H.-H. Staerfeldt, T. Rognes, D.W. Ussery, RNAmmer: consistent and rapid annotation of ribosomal RNA genes, Nucleic Acids Res. 35 (2007) 3100-3108, http://dx.doi.org/10.1093/nar/gkm160.

[25] L. Käll, A. Krogh, E.L.L. Sonnhammer, A combined transmembrane topology and signal peptide prediction method, J. Mol. Biol. 338 (2004) 1027-1036, http://dx.doi.org/10.1016/j.jmb.2004.03.016.

[26] P. Gouret, J.D. Thompson, P. Pontarotti, PhyloPattern: regular expressions to identify complex patterns in phylogenetic trees, BMC Bioinforma. 10 (2009) 298, http://dx.doi.org/10.1186/1471-2105-10-298.

[27] M. Lechner, S. Findeiß, L. Steiner, M. Marz, P.F. Stadler, S.J. Prohaska,
Proteinortho: detection of (Co-)orthologs in large-scale analysis, BMC Bioinforma. 12 (2011) 124, http://dx.doi.org/10.1186/1471-2105-12-124.

[28] D. Ramasamy, A.K. Mishra, J.-C. Lagier, R. Padhmanabhan, M. Rossi, E. Sentausa, et al., A polyphasic strategy incorporating genomic data for the taxonomic description of novel bacterial species, Int. J. Syst. Evol. Microbiol. 64 (2014) 384-391, http://dx.doi.org/10.1099/ijs.0.057091-0.

[29] A.F. Auch, M. von Jan, H.-P. Klenk, M. Göker, Digital DNA-DNA hybridization for microbial species delineation by means of genome-to-genome sequence comparison, Stand. Genom. Sci. 2 (2010) 117-134, http://dx.doi.org/10.4056/ sigs. 531120.

[30] J.P. Meier-Kolthoff, A.F. Auch, H.-P. Klenk, M. Göker, Genome sequence-based species delimitation with confidence intervals and improved distance functions, BMC Bioinforma. 14 (2013) 60, http://dx.doi.org/10.1186/1471-210514-60.

[31] P. Gouret, J. Paganini, J. Dainat, D. Louati, E. Darbo, P. Pontarotti, et al., Integration of evolutionary biology concepts for functional annotation and automation of complex research in evolution: the multi-agent software system DAGOBAH, in: P. Pontarotti (Ed.), Evol. Biol. - Concepts Biodivers. Macroevolution Genome Evol., Springer, Berlin Heidelberg, 2011, pp. 71-87. http:/ link.springer.com/chapter/10.1007/978-3-642-20763-1_5 (accessed 27.05.16).

[32] P. Gouret, V. Vitiello, N. Balandraud, A. Gilles, P. Pontarotti, E.G. Danchin, FIGENIX: intelligent automation of genomic annotation: expertise integration in a new software platform, BMC Bioinform. 6 (2005) 198, http://dx.doi.org 10.1186/1471-2105-6-198.

[33] C. Högenauer, C. Langner, E. Beubler, I.T. Lippe, R. Schicho, G. Gorkiewicz, et al. Klebsiella oxytoca as a causative organism of antibiotic-associated hemorrhagic colitis, N. Engl. J. Med. 355 (2006) 2418-2426, http://dx.doi.org/ 10.1056/NEJMoa054765.

[34] A.L. Brioukhanov, A.I. Netrusov, Catalase and superoxide dismutase: distribution, properties, and physiological role in cells of strict anaerobes, Biochemistry (Mosc) 69 (2004) 949-962.

[35] M.T. Khan, S.H. Duncan, A.J. Stams, J.M. van Dijl, H.J. Flint, H.J. Harmsen, The gut anaerobe Faecalibacterium prausnitzii uses an extracellular electron shuttle to grow at oxic-anoxic interphases, ISME J. 6 (2012) 1578-1585, http://dx.doi.org/10.1038/ismej.2012.5.

[36] N. Dione, S. Khelaifia, B. La Scola, J.C. Lagier, D. Raoult, A quasi-universal medium to break the aerobic/anaerobic bacterial culture dichotomy in clinical microbiology, Clin. Microbiol. Infect. 22 (2016) 53-58, http://dx.doi.org/ 10.1016/j.cmi.2015.10.032.

[37] S. Hirano, N. Matsumoto, M. Morita, K. Sasaki, N. Ohmura, Electrochemica control of redox potential affects methanogenesis of the hydrogenotrophic methanogen Methanothermobacter thermautotrophicus, Lett. Appl. Microbiol. 56 (2013) 315-321, http://dx.doi.org/10.1111/lam.12059.

[38] T. Ezaki, Y. Kawamura, N. Li, Z.Y. Li, L. Zhao, S. Shu, Proposal of the genera Anaerococcus gen. nov., Peptoniphilus gen. nov. and Gallicola gen. nov. for members of the genus Peptostreptococcus, Int. J. Syst. Evol. Microbiol. 51 (2001) 1521-1528, http://dx.doi.org/10.1099/00207713-51-4-1521.

[39] T. Ezaki, S.L. Liu, Y. Hashimoto, E. Yabuuchi, Peptostreptococcus hydrogenalis sp. nov. from human fecal and vaginal flora, Int. J. Syst. Evol. Microbiol. 40 (1990) 305-306, http://dx.doi.org/10.1099/00207713-40-3-305.

[40] Y. Song, C. Liu, S.M. Finegold, Peptoniphilus gorbachii sp. nov., Peptoniphilus olsenii sp. nov., and Anaerococcus murdochii sp. nov. isolated from clinica specimens of human origin, J. Clin. Microbiol. 45 (2007) 1746-1752, http:/ dx.doi.org/10.1128/JCM.00213-07.

[41] D.A. Murdoch, M.D. Collins, A. Willems, J.M. Hardie, K.A. Young, J.T. Magee, Description of three new species of the genus Peptostreptococcus from human clinical specimens: Peptostreptococcus harei sp. nov., Peptostreptococcus ivorii sp. nov., and Peptostreptococcus occtavius sp. nov, Int. J. Syst. Bacteriol. 47 (1997) 781-787, http://dx.doi.org/10.1099/00207713-47-3-781.

[42] N. Li, Y. Hashimoto, S. Adnan, H. Miura, H. Yamamoto, T. Ezaki, Three new species of the genus Peptostreptococcus isolated from humans: Pepstreptococcus vaginalis sp. nov., Pepstreptococcus lacrimalis sp. nov., and Peptostreptococcus lactolyticus sp. nov, Int. J. Syst. Bacteriol. 42 (1992) 602-605 http://dx.doi.org/10.1099/00207713-42-4-602.

[43] T. Ezaki, N. Yamamoto, K. Ninomiya, S. Suzuki, E. Yabuuchi, Transfer of Peptococcus indolicus, Peptococcus asaccharolyticus, Peptococcus prevotii and Peptococcus magnus to the genus Peptostreptococcus and proposal of Peptostreptococcus tetradius sp. nov, Int. J. Syst. Bacteriol. 33 (1983) 683-698. 